\title{
EDITORIAL
}

\section{Drones in wine and medicine}

(C) The Author(s), under exclusive licence to Springer Nature Limited 2021

Bone Marrow Transplantation (2022) 57:154-155; https://doi.org/ 10.1038/s41409-021-01511-7

\section{An unjust peace is better than a just war}

Marcus Tullius Cicero (known as Cicero). 106-43 BC. Roman Orator and Senator (Fig. 1).

The best-known Western artists to depict the horrors of war are two Spanish artists Francisco José de Goya y Luciens (known as Goya, 1746-1828) and Pablo Picasso. Goya was a prodigious artist and his painting 'The Third of May 1808' (Fig. 2) and series of etchings, 'The Disasters of War', are among his best-known antiwar artworks. Since the tenth century, war has become more deadly, primarily due to advancing technology, culminating in the dropping of the 'atomic bombs' on Japan towards the end of World War II (WWII). More recently, the use of drones in military conflicts has introduced yet another dimension to war.

Unmanned aerial vehicles (UAVs) or uncrewed aerial vehicles are commonly known as drones. Like many ideas, it took quite some time before the technology was perfected. Unmanned air balloons were used as early as 1849 when the Austrians tried to bomb Venice-they were unsuccessful [1]. The wind, thankfully, changed direction, and the balloons drifted back to the senders (Fig. 3)! Drones, for military purposes, were developed in the 1970s, although the V-1flying bombs were used by the Nazis during WWII. Drones were also spectacularly used by Israel in the Yom Kippur War in 1973. Apparently unarmed Israeli drones spurred Egypt to launch all its anti-aircraft missiles, paving the way for a virtually unimpeded subsequent air strike. Drones have increased in popularity since then and were widely used in the Gulf War in Iraq. Although aimed at terrorist targets, drones may kill innocent civilians [2, 3]. Although some people, including many soldiers, find war distasteful, the idea of sitting in a room, looking at a computer screen and pressing a button or clicking a mouse to cause the death of an individual or groups of people, perhaps thousands of miles away, seems, to me, particularly abhorrent.

However, not all drones are used for military reasons. Happily, drones have been used successfully in medicine, and the wine business. According to Graeme Lennox, writing in the Sunday Times, in August 2020 [4], robots, presumably drones, have been used to detect vine diseases and for precision spraying of chemicals. As well as the severe frost in early spring, which caused devastation to French and Italian wines [5], bush fires in California and Australia have added smoke-taint to the list of wine farmers' difficulties. A company called MathWorks teamed up with the University of Melbourne, Australia, to develop an algorithm, which, when fed into a drone, can detect faint traces of smoke taint. In a personal chat with $\mathrm{Dr}$ Fabio Mattioli from the Department of Social Anthropology, University of Melbourne, Australia he says: 'Winemaking offers a particularly interesting avenue to explore the implications of Al for professionals. On the one

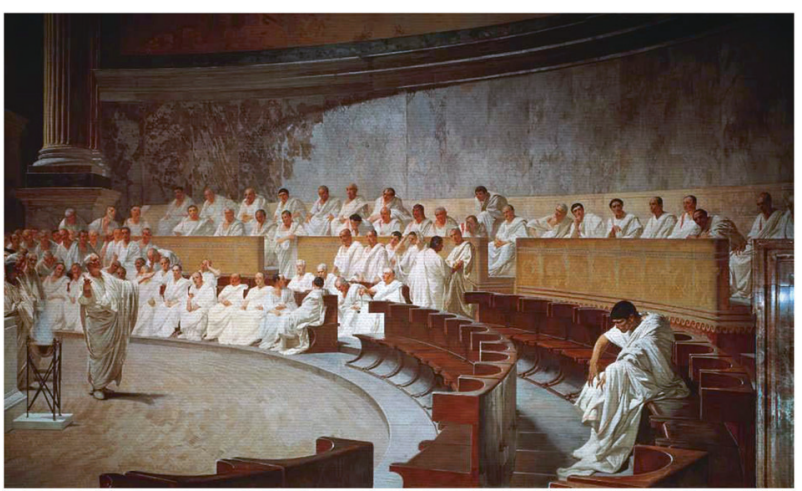

Fig. 1 Cicero. Cicero denouncing Catiline. Cesare Maccari (1840-1919). A portion of fresco above the door. Palazzo Madama, Rome, Italy. This work is in the public domain.

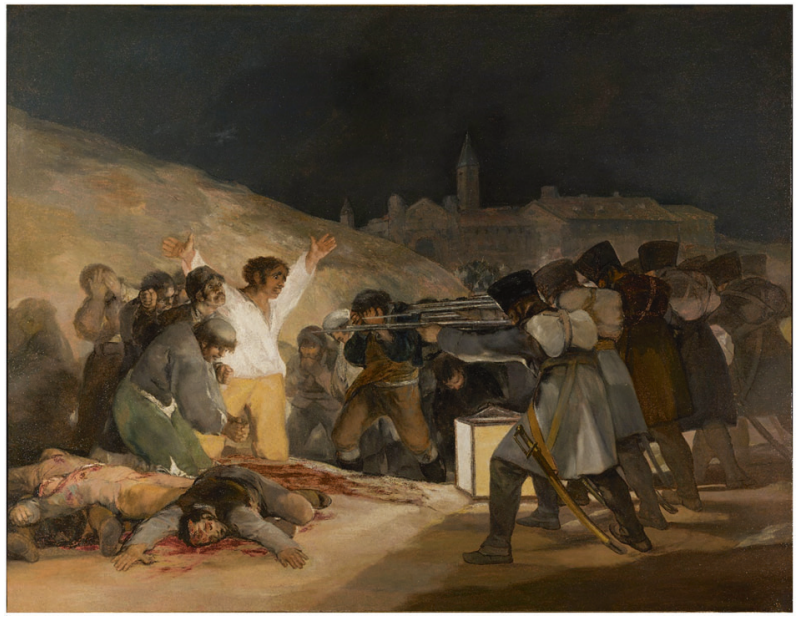

Fig. 2 The third of May 1808. Francisco Goya (1746-1828). Oil on canvas. Museo del Prado, Madrid, Spain. Wikimedia Commons.

hand, winemakers are highly trained specialists, who utilize new scientific developments and technological help to improve vineyards and the quality of their wine. On the other hand, many winemakers see wine as more than a chemical compound to be manipulated at will. For them, making wine is a craft. A sensory journey, which stems from an indefinable relationship between humans and nature; $a$ passion they nurture by curating and embedding their lives in the terroir.' He added: 'As an anthropologist, I am interested in how using drones might change what winemaking means to people who make or consume wine.' It seems that Australia is again proving to be a world leader in introducing new technology to winemaking.

The Australian Government is also researching the use of drones, in other ways, in vineyards. The researchers claim that if you equip a UAV with a normal camera and a long-range infrared 


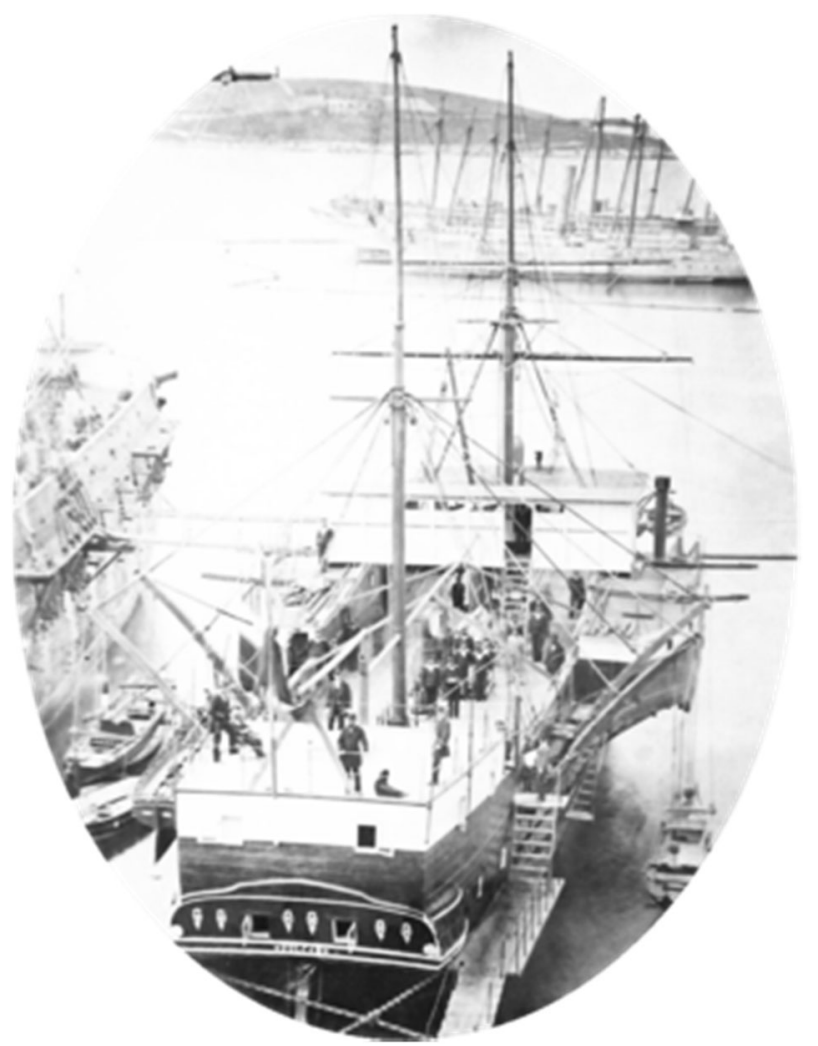

Fig. 3 SMS Vulcano, a paddle steamer in the Austro-Hungarian navy. Used as a balloon carrier to launch armed hot air balloons at Venice, 1849.

camera, set up to work as a temperature sensor, you can measure the temperature of vines, grapes, buds and the ground. So, perhaps in future years, drones will be used for spraying vines, measuring ground and vine temperature and many, as yet, unknown other tasks.

Do drones have a role to play in medicine? Yes. Initial interest was to deliver blood for transfusion to isolated areas, for example, in 2019 the Rwandan Blood Transfusion service delivered blood for transfusion by drone, using Zipline, which significantly reduced delivery times. Drones have also been used for many purposes including delivering vaccinations to children on an island in the Pacific Ocean, anti-venom solutions, human organs, and in 2019 Professor Derek O'Keefe from University College Galway (Ireland) and his team delivered insulin and glucagon to one of the Aran Islands (off the west coast of Ireland) using a drone and arranged for blood samples to be returned to the mainland. A comprehensive review of the use of drones by Rosser and colleagues was published in 2018 [6].

A group of enterprising doctors, led by Dr Eoin Fogarty, in Cork (south of Ireland) have experimented with drones delivering blood/blood products to ships at sea. Using a commercial drone (DJIM600) they delivered blood to a ship, but experienced difficulty in landing, so they dropped the blood into the sea, from where it was rescued. They found no evidence of red cell degradation, specifically, there was no haemolysis. According to Eoin (personal communication) the sea temperature, off that coast, was about $10^{\circ} \mathrm{C}$, so the blood could have safely floated for $24 \mathrm{~h}$.

I don't know if drones have been used to deliver wine to thirsty customers but, no doubt, that day will come!

\author{
Shaun R. McCann (D) $^{1 凶}$ \\ ${ }^{1}$ Emeritus Department of Haematology, Trinity College Dublin, \\ Dublin, Ireland. ${ }^{\circledR}$ email: shaunrmccann@gmail.com
}

\section{REFERENCES}

1. Reade L. Bombs over Venice. Vol. 8 (6). London: History Today Ltd; 1958.

2. MacGuill D. Former US drone operators: 'The innocent civilians we killed only fuelled the terrorism of ISIS'. Ireland: The journal.ie. Distilled Media; 2015.

3. Aikins M, Koettl C, Hill E, Schmitt E. Evidence undercuts drone strike justification. International Edition. New York: The New York Times Company; 2021. p. 1-2.

4. Lennox G. The grape agritech awakening. The Sunday Times. UK: The Times Newspapers Ltd; 2020.

5. McCann SR. The effect of weather on HCT and vines. Bone Marrow Transplant. 2021;56:2321-23.

6. Rosser JC, Vudatha V, Terwilleger BA, Parker BC. Surgical and medical applications of drones: a comprehensive review. JSLS 2018;21:e2018.

\section{AUTHOR CONTRIBUTIONS}

S.M.C. is the sole contributor and writer of this article.

\section{COMPETING INTERESTS}

The author declares no competing interests.

\section{ADDITIONAL INFORMATION}

Correspondence and requests for materials should be addressed to Shaun $R$. McCann.

Reprints and permission information is available at http://www.nature.com/ reprints

Publisher's note Springer Nature remains neutral with regard to jurisdictional claims in published maps and institutional affiliations. 